\title{
Zaznane značilnosti delovnega mesta in čustveno delo kot dejavniki delovne zavzetosti učiteljev
}

\author{
Katja Košir*, Sara Tement in Marina Horvat \\ Oddelek za psihologijo, Filozofska fakulteta, Univerza v Mariboru
}

\begin{abstract}
Povzetek: Delovna zavzetost učiteljev predstavlja pomemben dejavnik kakovosti njihovega poučevanja ter njihovega vedenja v razredu. Razumevanje dejavnikov, ki prispevajo k visoki stopnji delovne zavzetosti učiteljev, je ključno za spodbujanje kakovostnega vzgojnoizobraževalnega dela. Dosedanje raziskave tudi pri poklicni skupini učiteljev kažejo, da predstavljajo zaznane značilnosti delovnega okolja pomemben dejavnik delovne zavzetosti. Obenem se kot pomembna značilnost dela učiteljev kaže potreba po čustvenem delu, pri čemer lahko slednje predstavlja tako delovno zahtevo kot delovni vir. Namen pričujoče raziskave je bil izhajajoč iz modela delovnih zahtev in virov preveriti samozaznane delovne zahteve (splošne delovne obremenitve) in delovne vire (avtonomija, opora sodelavcev, opora nadrejenih) kot dejavnike delovne zavzetosti učiteljev na vzorcu 344 učiteljev iz 22 slovenskih osnovnih šol. Prav tako smo želele preveriti potencial strategij čustvenega dela kot bodisi dejavnika tveganja bodisi varovalnega dejavnika za delovno zavzetost učiteljev. Rezultati so pokazali, da predstavlja zaznana avtonomija pozitiven napovednik delovne zavzetosti ter da ima čustveno delo potencial, da predstavlja tako delovno zahtevo kot delovni vir. Površinsko čustveno delovanje se je namreč izkazalo za negativen napovednik delovne zavzetosti, globinske strategije pa so predstavljale pozitiven napovednik delovne zavzetosti. Na osnovi ugotovitev predlagamo nekatere ukrepe za povišanje delovne zavzetosti učiteljev.
\end{abstract}

Ključne besede: učitelji, delovna zavzetost, model delovnih zahtev in virov, čustveno delo

\section{Perceived job characteristics and emotional labor as factors of teachers' work engagement}

\author{
Katja Košir*, Sara Tement and Marina Horvat \\ Department of Psychology, Faculty of Arts, University of Maribor, Slovenia
}

\begin{abstract}
Teachers' work engagement determines the quality of their teaching and classroom behavior. Understanding the factors that contribute to a high level of teacher engagement is thus crucial to promoting quality educational work. The existing research shows that the perceived characteristics of the working environment are an important factor of work engagement in teachers. At the same time, an important characteristic of teachers' work is the need for emotional labor; the latter can represent either a job demand or a job resource. Based on the job demands-resources model, the purpose of the present research was to examine perceived job demands (workload) and job resources (autonomy, coworker and supervisor support) as factors of teachers' work engagement on a sample of 344 teachers from 22 Slovenian elementary schools. In addition, we aimed to examine the potential of emotional labor strategies as either a risk factor or a protective factor for teachers' work engagement. The results indicated that perceived autonomy positively predicted teachers' work engagement and that emotional labor had the potential to represent both a job demand and a job resource. Surface acting was found to negatively predict work engagement, whereas deep acting was a positive predictor of work engagement. Based on our findings, we propose some measures to increase teachers' work engagement.
\end{abstract}

Keywords: teachers, work engagement, job demands-resources model, emotional labor

\footnotetext{
${ }^{*}$ Naslov/Address: izr. prof. dr. Katja Košir, Oddelek za psihologijo, Filozofska fakulteta, Univerza v Mariboru, Koroška cesta 160, 2000 Maribor, e-mail: katja.kosir@um.si

Članek je licenciran pod pogoji Creative Commons Attribution 4.0 International licence. (CC-BY licenca).

The article is licensed under a Creative Commons Attribution 4.0 International License (CC-BY license).
} 
Ugotovitve sodobnih raziskav, ki so preučevale ključne dejavnike učne uspešnosti učencev kažejo, da je vedenje učitelja eden ključnih napovednikov učnih dosežkov učencev (za pregled glej npr. Hattie, 2009; Hattie in Anderman, 2013). Delovna zavzetost učiteljev predstavlja pomemben dejavnik kakovosti njihovega poučevanja in njihovega vedenja $\mathrm{v}$ razredu (Bakker in Ball, 2010) ter posredno sooblikuje tudi zavzetost in učne dosežke učencev (Watt in Richardson, 2013). Razumevanje dejavnikov, ki prispevajo k visoki stopnji delovne zavzetosti učiteljev, je tako ključno za spodbujanje kakovostnega vzgojno-izobraževalnega dela.

Dosedanje raziskave (npr. Bakker, Hakanen, Demerouti in Xanthopoulou, 2007; Hakanen, Schaufeli in Ahola, 2008) kažejo, da predstavljajo zaznane značilnosti delovnega okolja pomemben dejavnik delovne zavzetosti, kar potrjujejo tudi raziskave, izvedene na poklicni skupini učiteljev (Hakanen, Bakker in Schaufeli, 2006; Simbula, Guglielmi in Schaufeli, 2011). Namen pričujoče raziskave je izhajajoč iz modela delovnih zahtev in virov (Bakker in Demerouti, 2007; Bakker, Demerouti, De Boer in Schaufeli, 2003; Demerouti, Bakker, Nachreiner in Schaufeli, 2001) preveriti samozaznane delovne zahteve (splošne delovne obremenitve) in delovne vire (opora sodelavcev, opora nadrejenih, avtonomija) kot dejavnike delovne zavzetosti učiteljev na vzorcu slovenskih učiteljev osnovne šole. $\mathrm{Ob}$ tem smo izhajale iz posebnosti dela učiteljev kot izrazito odnosnega dela ter ob prej navedenih delovnih zahtevah in virih kot pomembno delovno zahtevo preverile tudi čustveno delo učiteljev - torej uravnavanje izražanja lastnih čustev v skladu s pravili organizacije ali stroke (Hochschild, 1983). Slednje smo v raziskavi operacionalizirale kot samoporočano uporabo površinskih oziroma globinskih strategij čustvenega dela, pri čemer se prve nanašajo na pretvarjanje oziroma simuliranje določenih v situaciji primernih čustev, druge pa na aktivno uravnavanje lastnih čustev tako, da sta izražanje in doživljanje čustev skladna (Hochschild, 1983). V pričujoči raziskavi smo površinske in globinske strategije čustvenega dela preverile kot dejavnika delovne zavzetosti učiteljev; zanimal nas je potencial strategij čustvenega dela kot bodisi dejavnika tveganja bodisi varovalnega dejavnika za delovno zavzetost učiteljev.

\section{Delovna zavzetost učiteljev}

Delo učitelja zahteva zelo raznolika znanja in spretnosti; med najpomembnejšimi so recimo dobro poznavanje vsebin, ki jih poučuje, strategije poučevanja, strategije postavljanja ciljev in načrtovanja, strategije vodenja razreda, komunikacijske strategije, zmožnost vzpostavljanja podpornih odnosov z zelo raznolikimi učenci in zmožnost fleksibilnega odzivanja. Uspešnost spoprijemanja z zahtevami, ki jih prinaša poklic učitelja, v veliki meri določa razvoj kariere zaposlenega, saj lahko vodi bodisi v izgorelost bodisi v krepitev delovne zavzetosti. Slednja predstavlja pozitiven izid in hkrati dejavnik uspešnega spoprijemanja z delovnimi nalogami (Simbula idr., 2011) in je opredeljena kot pozitivno, izpolnjujoče, $\mathrm{Z}$ delom povezano stanje, ki ga raziskovalci (npr. Bakker, Schaufeli, Leiter in Taris, 2008; Schaufeli in Bakker, 2004a) opredeljujejo na treh dimenzijah. Energija se nanaša na visoko stopnjo energetske opremljenosti in mentalne odpornosti pri delu, na pripravljenost vlaganja truda v delo ter na vztrajanje, ko se pri delu pojavijo ovire. Predanost vključuje občutek osmišljenosti, entuziazma, navdiha, ponosa in izziva pri delu. Zatopljenost pa pomeni popolno osredotočenost in vključenost $\mathrm{v}$ delo, pri čemer čas hitro mineva in se posameznik težko loči od dela (Bakker idr., 2008). Nekatere raziskave (npr. GonzálezRomá, Schaufeli, Bakker in Lloret, 2006) nakazujejo, da sta energija in predanost jedrni dimenziji zavzetosti ter da na ta način operacionaliziran konstrukt zavzetosti predstavlja nasprotni pol izgorelosti, operacionalizirani z dimenzijama izčrpanosti in depersonalizacije oziroma cinizma. Vendar pa na vprašanje, ali predstavlja delovna zavzetost nasprotni pol izgorelosti ali pa gre za dva sicer povezana, a neodvisna koncepta, raziskave zaenkrat še ne dajejo jasnega odgovora (glej npr. Taris, Ybema in van Beek, 2017). So pa raziskave v preteklih dveh desetletjih pokazale, da konstrukta delovne zavzetosti ni mogoče enačiti $\mathrm{z}$ nekaterimi sorodnimi konstrukti, kot sta npr. predanost organizaciji (Hallberg in Schaufeli, 2006) ali deloholizem (Schaufeli, Taris in Bakker, 2006) ter da delovna zavzetost učiteljev pozitivno napoveduje kakovostno poučevanje (Bakker in Ball, 2010).

\section{Dejavniki delovne zavzetosti: značilnosti dela učiteljev kot delovne zahteve in delovni viri}

Značilnosti dela so pomemben dejavnik dobrobiti zaposlenih in napovedujejo tako izgorelost kot zavzetost pri delu. Sodobne raziskave dejavnikov delovne zavzetosti (kakor tudi izgorelosti) pretežno izhajajo iz modela delovnih zahtev in virov (Bakker in Demerouti, 2007; Bakker idr., 2003; Demerouti idr., 2001), ki opredeljuje dve kategoriji značilnosti delovnega mesta: delovne zahteve in delovne vire. Delovne zahteve so fizični, psihološki, socialni ali organizacijski vidiki dela, ki od posameznika zahtevajo stalna fizična in/ ali psihološka prizadevanja in so povezane $\mathrm{z}$ določenimi fiziološkimi in/ali psihološkimi stroški (Demerouti idr., 2001). Delovne zahteve sicer niso stresorji same po sebi, lahko pa to postanejo v situacijah, ki zahtevajo visoko prizadevanje, da bi ohranili pričakovano raven izvedbe. Na ta način lahko torej visoke delovne zahteve prispevajo k izgorelosti pri delu. Delovni viri se nanašajo na tiste fizične, psihološke, socialne ali organizacijske vidike dela, ki (1) lahko zmanjšajo delovne zahteve in z njimi povezane fiziološke ali psihološke stroške; (2) so posamezniku v pomoč pri doseganju delovnih ciljev in (3) spodbujajo osebnostno rast, učenje in razvoj. Delovni viri naj bi tako predstavljali najpomembnejši napovednik delovne zavzetosti (Schaufeli in Bakker, 2004a). Tako so Bakker idr. (2007) na velikem vzorcu finskih učiteljev osnovne in srednje šole ugotovili, da predstavljajo opora nadrejenega, inovativnost, spoštovanje in ugodna organizacijska klima pomembne delovne vire, ki učiteljem pomagajo ohranjati visoko delovno zavzetost ob spoprijemanju $\mathrm{z}$ zahtevnim vedenjem učencev oziroma dijakov, torej tudi $\mathrm{v}$ pogojih visokih delovnih zahtev. Hakanen idr. (2006) pa so prav tako na vzorcu finskih učiteljev potrdili osnovni predpostavki modela, torej da so delovne zahteve napovedniki izgorelosti 
na delovnem mestu, delovni viri pa napovedujejo delovno zavzetost. Simbula idr. (2011) so v vzdolžni raziskavi na vzorcu italijanskih učiteljev ugotovili recipročen odnos med delovnimi viri, operacionaliziranimi kot zaznane priložnosti za učenje, opora nadrejenih, opora sodelavcev ter samoučinkovitost, in delovno zavzetostjo; zaznani delovni viri so prispevali $\mathrm{k}$ višji delovni zavzetosti, ta pa je vodila $\mathrm{v}$ zaznavanje višnje stopnje delovnih virov v posameznikovem delovnem okolju. Ugotovitev nakazuje, da lahko zavzeti učitelji soustvarjajo delovne vire v svojem delovnem okolju - spodbujajo vzajemno oporo sodelavcev ter ustvarjajo priložnosti za poklicno učenje.

Košir, Licardo, Tement in Habe (2014) so preverjale odnos med delovnimi zahtevami in viri ter stresom in izgorelostjo pri delu na vzorcu slovenskih osnovnošolskih učiteljev. Ugotovile so, da predstavljajo splošne delovne obremenitve najmočnejši napovednik stresa, čustvene izčrpanosti in depersonalizacije: učitelji, ki so pri svojem delu zaznavali višjo stopnjo delovnih obremenitev, so poročali o višji stopnji doživljanja stresa, čustvene izčrpanosti in depersonalizacije. Delovni viri, operacionalizirani kot avtonomija, opora sodelavcev in opora nadrejenih, so negativno napovedovali doživljanje stresa in čustvene izčrpanosti, ne pa tudi depersonalizacije, pri čemer je bila napovedna moč delovnih virov v primerjavi $\mathrm{z}$ delovnimi zahtevami šibkejša. Raziskava je torej na vzorcu slovenskih učiteljev potrdila povezanost med delovnimi zahtevami in viri ter izgorelostjo pri delu. Med raziskavami, izvedenimi na slovenskem vzorcu, ki so preučevale odnos med delovnimi zahtevami in viri ter pozitivnimi izidi pri učiteljih, velja omeniti tudi raziskavo avtoric Habe in Tement (2016), ki sta potrdili pozitiven odnos med delovnimi viri in dimenzijami zanosa pri slovenskih visokošolskih učiteljih. Nimamo pa še raziskav, ki bi preverjale odnos med delovnimi zahtevami in viri ter delovno zavzetostjo učiteljev. Eden od namenov pričujoče raziskave je zapolniti to raziskovalno vrzel. Preveriti smo nameravale, v kolikšni meri ter na kakšen način zaznane značilnosti delovnega mesta, opredeljene kot delovne zahteve (delovne obremenitve) in delovni viri (opora sodelavcev in nadrejenih, avtonomija) napovedujejo delovno zavzetost učiteljev osnovne šole. Predpostavile smo, da delovne obremenitve negativno napovedujejo delovno zavzetost (H1), medtem ko so delovni viri pozitivni napovedniki delovne zavzetosti $(\mathrm{H} 2)$.

\section{Čustveno delo učiteljev: delovna zahteva ali delovni vir?}

Raziskave torej potrjujejo pozitiven odnos med delovnimi viri in delovno zavzetostjo pri učiteljih. Vendar pa se je večina raziskav osredotočala na vire, povezane z organizacijsko klimo $\mathrm{v}$ delovnem kolektivu (npr. avtonomija, opora sodelavcev in nadrejenih, zaznane priložnosti za učenje) oziroma splošnimi notranjimi viri, kot je samoučinkovitost (Simbula idr. 2011). Redke pa so raziskave (npr. Philipp in Schüpbach, 2010), ki so naslovile tiste značilnosti dela učiteljev, ki se nanašajo na njihovo zmožnost vzpostavljati podporne odnose $\mathrm{z}$ učenci ter preverjale, na kak način se slednje povezujejo z delovno zavzetostjo - torej ali predstavljajo delovno zahtevo ali delovni vir. Sposobnost učitelja, da vzpostavlja podporne odnose $\mathrm{z}$ učenci se namreč kaže kot ena ključnih poklicnih kompetenc učitelja, ki je za spodbujanje kakovostnega poučevanja enako pomembna ali celo pomembnejša kot dobre didaktične ali predmetno specifične kompetence (Cornelius-White, 2007). Pri tem raziskave (npr. Košir idr., 2014; Slivar, 2009) kažejo, da je prav slednje, torej zahteva po stalnem odzivanju na raznolike potrebe učencev, eden izmed ključnih stresorjev pri delu učiteljev, obenem pa naj bi prav odnosni vidiki dela predstavljali ključni dejavnik delovnega zadovoljstva učiteljev (Tsang, 2011); imajo torej potencial, da predstavljajo tako delovno zahtevo kot delovni vir. Koncept, ki bi utegnil pojasniti dvojno naravo odnosa med odnosnimi značilnostmi dela in dobrobitjo učiteljev, je čustveno delo (Hochschild, 1983), tj. konstrukt, ki se nanaša na uravnavanje izražanja lastnih čustev $\mathrm{v}$ skladu s pravili (organizacije). Avtorica koncepta je izhajala iz teze, da se čustva zaposlenih tržijo kot dobrine, kar vodi v zahteve po uravnavanju oziroma izražanju čustev v številnih poklicnih vlogah (npr. storitveni poklici). V zadnjem desetletju se je povečalo tudi zanimanje raziskovalcev s področja psihologije za ta pojav, znotraj tega pa tudi zavedanje, da je tudi delo učitelja $\mathrm{v}$ veliki meri čustveno delo. Učitelji morajo $\mathrm{v}$ komunikaciji z učenci, starši in sodelavci pogosto skrivati svoja čustva ali izražati čustva, ki jih dejansko ne občutijo: učne vsebine predstavljati zavzeto in z zanosom, izraziti navdušenje nad predlogi učencev, prikriti svoja občutja nemoči ob disciplinsko problematičnem razredu ter ostati mirni in strokovni v komunikaciji s starši, ki so kritični do njihovega dela (Košir, 2017; Tösten in Sahin, 2017). Pri tem je pomembno razločevati med dvema strategijama čustvenega dela, saj lahko poteka bodisi s površinskim delovanjem (angl. surface acting) bodisi z globinskim delovanjem (angl. deep acting). $\mathrm{V}$ primeru površinskega delovanja posameznik čustva, ki jih želi pokazati, simulira in jih dejansko ne občuti, jih torej odigra in se pretvarja (npr. učitelj se ob motečem vedenju učenca poskuša odzvati mirno, čeprav je jezen nanj). Pri globinskem delovanju pa gre za to, da posameznik svoje čustvene odzive oblikuje aktivno, kar pomeni, da jih skuša dejansko tudi občutiti. Tako si lahko učitelj na primer prizadeva razumeti situacijo motečega učenca iz neurejenega družinskega okolja in njegova začetna jeza se lahko spremeni $\mathrm{v}$ naklonjenost do tega učenca. Globinsko delovanje torej pomeni tudi spremembo notranjega čustvenega stanja, medtem ko površinsko delovanje pomeni le izražanje čustva, ki ga posameznik dejansko ne občuti.

Philipp in Schüpbach (2010) sta longitudinalno preučevala čustveno delo v odnosu do stopnje izčrpanosti ter predanosti delu pri učiteljih. Ugotovila sta, da je uporaba površinskih strategij čustvenega dela $\mathrm{v}$ obdobju enega leta pomemben napovednik čustvene izčrpanosti, obenem pa čustvena izčrpanost vodi v večjo stopnjo uporabe površinskih strategij čustvenega dela. Učitelji, ki so pretežno uporabljali površinsko igranje, so bili v večji meri utrujeni, razdražljivi in čustveno nestabilni. Nasprotno pa je bila pri učiteljih, ki so izražali in občutili pristna čustva, torej so uporabljali globinske strategije čustvenega dela, stopnja izčrpanosti nižja, obenem pa so poročali o višji stopnji predanosti delu. Podobne so ugotovitve avtorjev Yang in Li (2009), ki poročata, da se površinske strategije čustvenega dela negativno, globinske strategije pa pozitivno povezujejo z delovnim zadovoljstvom učiteljev. Tudi raziskave, izvedene na vzorcih drugih zaposlenih, kažejo, da 
se čustveno delo $\mathrm{z}$ duševnim zdravjem zaposlenih povezuje tako negativno kot pozitivno, in sicer $\mathrm{v}$ odvisnosti od tega, ali gre za uporabo površinskih oziroma globinskih strategij čustvenega dela; pri tem večina raziskav poroča o negativnih učinkih uporabe površinskih strategij čustvenega dela na različne vidike doživljanja zaposlenih, medtem ko raziskave, ki so preučevale uporabo globinskih strategij čustvenega dela, ne omogočajo jasnih zaključkov o učinkih na različne vidike psihološke prilagojenosti zaposlenih (Hülsheger in Schewe, 2011; Judge, Woolf in Hurst, 2009)

Izhajajoč iz predpostavke, da je prav nujnost stalnega uravnavanja lastnih čustev bodisi zuporabo površinskih bodisi z uporabo globinskih strategij ena izmed ključnih značilnosti dela učitelja, smo v raziskavi želele preveriti, kako se uporaba površinskih in globinskih strategij čustvenega dela povezuje z delovno zavzetostjo učiteljev osnovne šole. Predpostavile smo, da predstavlja uporaba površinskih strategij čustvenega dela negativen napovednik delovne zavzetosti (H3a), uporaba globinskih strategij čustvenega dela pa pozitivno napoveduje delovno zavzetost (H3b). Prav tako nas je zanimalo, ali koncept čustvenega dela pojasni dodaten delež variance v delovni zavzetosti učiteljev, ki ga ni mogoče pojasniti s splošnimi delovnimi obremenitvami in viri.

\section{Metoda}

\section{Udeleženci}

V raziskavi je sodelovalo skupno 344 učiteljic in učiteljev iz 22 različnih slovenskih osnovnih šol. Od tega je bilo v $86,3 \%$ žensk $(n=297)$ in $11,6 \%$ moških $(n=40)$, ostali udeleženci $(n=7)$ podatka o spolu niso navedli. Povprečna starost učiteljev v vzorcu je bila 45,30 let $(S D=8,70)$, povprečna delovna doba učiteljev bila 20,40 let $(S D=10,44)$. Vzorec po osnovnih demografskih podatkih ne odstopa od značilnosti osnovnošolskih učiteljev $\mathrm{v}$ slovenskem izobraževalnem sistemu (SURS, 2018). Povprečno število sodelujočih učiteljic in učiteljev na posamezno osnovno šolo je bilo 15,63. 29,4 \% učiteljic in učiteljev je poučevalo v 1 . vzgojno-izobraževalnem obdobju ( $n=101) ; 14,5 \%$ v 2. vzgojno-izobraževalnem obdobju ( $n=50) ; 27,3 \%$ v 3 . vzgojno-izobraževalnem obdobju $(n=94) ; 25,5 \%$ jih je sodelovalo v pedagoškem procesu v več vzgojno-izobraževalnih obdobjih $(n=89), 2,9 \%$ učiteljev na vprašanje ni odgovorilo $(n=10)$.

\section{Pripomočki}

Vprašalnik delovnih zahtev in virov (Tement in Korunka, 2013; Tement, Korunka in Pfifer, 2010) je vprašalnik, ki zajema splošne delovne zahteve (5 postavk), avtonomijo (3 postavke), oporo s strani sodelavcev (4 postavke) in nadrejenih (4 postavke). Lestvica delovnih zahtev je prevzeta od avtorjev Boyar, Carr, Mosley in Carson (2007), ostale lestvice pa so sestavljene po zgledu drugih uveljavljenih vprašalnikov (npr. Job Content Questionnaire; Karasek idr., 1998). Vprašalnik vključuje postavke, vezane na omenjene značilnosti delovnega mesta. Udeleženci jih ovrednotijo s pomočjo petstopenjske odgovorne lestvice ( 1 - sploh se ne strinjam; 5 - popolnoma se strinjam). Primer postavke, ki meri delovne zahteve: Moje delo od mene veliko zahteva; primer postavke, ki meri delovne vire (avtonomija): Pri delu lahko pogosto odločam o tem, katere delovne naloge bom opravil/-a.

$\mathrm{V}$ preteklih raziskavah se je na slovenskem vzorcu pokazalo, da ima vprašalnik zadovoljive merske značilnosti (Košir idr., 2014; Tement idr., 2010). Tudi na našem vzorcu ima vprašalnik zadovoljivo visoko zanesljivost, korelacije z drugimi konstrukti pa kažejo na ustrezno veljavnost uporabljenega instrumenta (glej tabelo 1 v Rezultatih).

Vprašalnik čustvenega dela (Emotional Labour Scale (ELS); Brotheridge in Lee (2003), prirejeno po Smrke in Tement, $\mathrm{v}$ pripravi) je samoocenjevalni vprašalnik, ki vsebuje 15 postavk in meri šest vidikov čustvenega dela: trajanje, pogostost, intenzivnost, raznolikost izražanja čustev ter površinsko in globinsko delovanje. Za potrebe pričujoče raziskave sta bili $\mathrm{v}$ analizah uporabljeni samo zadnji dve dimenziji, tj. površinsko in globinsko delovanje (za definicijo glej Uvod), vsaka s tremi postavkami. Postavke se nanašajo na pogostost izražanja določenih čustev na povprečen delovni dan. Vprašalnik vsebuje postavke, kot na primer: »Kako pogosto na povprečen delovni dan ... se upirate izražanju svojih pravih občutkov« (površinsko) / ... »skušate dejansko doživeti čustva, ki jih morate pokazati« (globinsko). Udeleženci na postavke odgovarjajo s pomočjo petstopenjske lestvice pogostosti ( 1 - nikoli, 5 - vedno).

Avtorji izvirne oblike vprašalnika poročajo o dobri konvergentni in divergentni veljavnosti vprašalnika, kot tudi o ustrezni zanesljivosti (Cronbach $\alpha=0,83$ za površinsko in $\alpha=0,79$ za globinsko delovanje) (Brotheridge in Lee, 2003). Uporabljena oblika vprašalnika $v$ tej raziskavi je bila prevedena iz angleškega $\mathrm{v}$ slovenski jezik $\mathrm{z}$ dvema neodvisnima prevodoma ter usklajena $\mathrm{v}$ enotni prevod. Preliminarni rezultati na slovenski populaciji kažejo dobre merske značilnosti uporabljenega instrumenta (Smrke in Tement, v pripravi). Enako se je pokazalo tudi na pričujočem vzorcu (glej tabelo $1 \mathrm{v}$ Rezultatih).

Vprašalnik delovne zavzetosti - kratka oblika (Work engagement questionnaire - short from (UWES - 9); Schaufeli, Bakker in Salanova (2006), slovenska priredba: Tement, 2014) meri tri dimenzije delovne zavzetosti: energija, predanost in zatopljenost $\mathrm{v}$ delo. Vsaka dimenzija vsebuje tri postavke. Primer postavke iz vprašalnika (zatopljenost): Srečen/-na sem, kadar intenzivno delam. Udeleženci na vsako postavko oz. opisano počutje odgovorijo s pomočjo sedemstopenjske lestvice pogostosti od 0 (nikoli) do 6 (vedno, vsak dan). Vprašalnik lahko obravnavamo ločeno po posameznih dimenzijah ali uporabimo skupni seštevek vseh postavk (Schaufeli in Bakker, 2004b) kot skupno mero delovne zavzetosti, kot smo ga uporabile tudi v tej raziskavi.

$\mathrm{V}$ preteklih raziskavah poročajo o dobrih merskih značilnostih vprašalnika tako $\mathrm{v}$ izvorni obliki (Schaufeli idr., 2006), kot tudi v slovenski priredbi (Tement, 2014). Tudi na našem vzorcu ima vprašalnik ustrezne psihometrične značilnosti (glej tabelo $1 \mathrm{v}$ Rezultatih). 


\section{Postopek}

Zbiranje podatkov je potekalo $\mathrm{v}$ okviru obsežnejše raziskave na temo medvrstniškega nasilja $\mathrm{v}$ slovenskih osnovnih šolah (Košir, Pivec, Klasinc, Špes in Horvat, 2018), katere namen je bil preveriti, $v$ kolikšni meri različni dejavniki medvrstniškega nasilja na različnih ravneh (dejavniki na ravni šole, dejavniki na ravni razreda, dejavniki na ravni posameznega učenca) določajo medvrstniško vedenje na šoli. Del podatkov v okviru omenjene obsežnejše raziskave je bil pridobljen od učencev, del podatkov pa od učiteljev. Pričujoč prispevek temelji samo na podatkih učiteljev in $\mathrm{V}$ nobeni obliki še ni bil predhodno objavljen.

Pred pričetkom zbiranja podatkov smo pridobile soglasje odgovornih oseb na osnovnih šolah za izvedbo raziskave ter $\mathrm{k}$ sodelovanju povabile učitelje iz vseh 22 vključenih šol. Sodelovanje v raziskavi je bilo prostovoljno, udeleženci so vprašalnike izpolnjevali po metodi papir-svinčnik. Udeležencem $\mathrm{v}$ raziskavi smo zagotovile anonimnost in možnost prekinitve sodelovanja. Šole, ki so sodelovale $\mathrm{v}$ raziskavi, so $\mathrm{v}$ zameno za sodelovanje dobile povratne informacije dobljenih izsledkov, prav tako je na šolah bila izvedena delavnica na temo preprečevanja medvrstniškega nasilja za učence. Raziskavo je potrdila Komisija za etičnost raziskovanja na Filozofski fakulteti Univerze v Mariboru.

\section{Statistične analize}

Skladno z namenom raziskave so nas zanimali odnosi med dejavniki delovnega mesta in delovno zavzetostjo na ravni posameznikov. Vendar pa so podatki na našem vzorcu učiteljev gnezdeni znotraj osnovnih šol, kar pomeni, da se deleži variance v odvisni spremenljivki (tj. delovna zavzetost) lahko nahajajo na ravni šol (2. raven) in na ravni posameznih učiteljev (1. raven). V kolikor se relevanten delež variabilnosti nahaja tudi na ravni šole, je to potrebno ustrezno upoštevati pri postopkih statističnih analiz in interpretaciji rezultatov. Običajne regresijske analize $\mathrm{v}$ takšnem primeru namreč ne dajejo ustrezne ocene regresijskih parametrov. Zato smo v prvem koraku ocenile deleže variance na posameznih ravneh. V te namene smo uporabile večnivojsko modeliranje v programu Mplus 7.4 (Muthén in Muthén; 1998-2017), v okviru katerega smo izračunale ničelne dvonivojske modele (angl. intercept only model). Za oceno deleža variabilnosti na posamezni ravni se uporablja koeficient intraklasne korelacije (angl. intraclass correlation, ICC), ki odraža korelacijo dveh naključno izbranih enot $\mathrm{v}$ odvisni spremenljivki znotraj enake skupine (v našem primeru šole). Pri delovni zavzetosti se je pokazalo, da je intraklasna korelacija nezanemarljiva $(\mathrm{ICC}=0,094)$. To pomeni, da je 9,4\% variance $\mathrm{v}$ delovni zavzetosti mogoče pripisati variabilnosti na ravni šol. Variabilnost na posameznih ravneh je zato potrebno upoštevati pri vseh nadaljnjih analizah.

Pred preverjanjem hipotez smo preverile faktorsko strukturo uporabljenih instrumentov $\mathrm{v}$ programu Mplus. Gnezdeno naravo podatkov smo $\mathrm{v}$ analizah upoštevale na način, da smo odgovore posameznikov na posamezni postavki centrirale na ravni posamezne šole (angl. groupmean centering). Tovrstno centriranje odpravi problematiko gnezdenih podatkov, saj odstrani razlike v povprečjih med šlami; koeficienti intraklasne korelacije za posamezne podatke so tako enaki 0 (Bear, Gaskins, Blank in Chen, 2011). Pri konfirmatorni faktorski analizi smo uporabile standardne mere prileganja in se ravnale po uveljavljenih smernicah za oceno prileganja: razmerje med hi-kvadratom in stopnjami svobode naj bo približno $2: 1$, vrednosti pri primerjalnih indeksov TLI in CFI naj bodo nad 0,9 in čim bližje 1, vrednosti indeksa RMSEA pod 0,08 in vrednosti indeksa pod 0,06 (Brown, 2006; McDonald in Ho, 2002).

Glavni del analiz je predstavljala večnivojska regresijska analiza, v kateri smo upoštevale gnezdeno naravno podatkov. Analiza je bila izvedena $\mathrm{v}$ programu Mplus preko ukaza TYPE=TWOLEVEL RANDOM. Delovne zahteve in viri (tj. splošne delovne zahteve, avtonomija, opora sodelavcev, opora nadrejenih) ter površinsko in globinsko delovanje so bili dodani kot napovedniki na ravni posameznikov. Vse spremenljivke na ravni posameznika so bile centrirane na posamezno šolo (angl. group-mean centering), torej glede na povprečne vrednosti vsake šole. Vrednosti tako odražajo odklon od povprečne vrednosti šole, s čimer odpravimo razlike med šolami in upoštevamo gnezdeno naravo podatkov. Spremenljvike na drugi ravni (tj. ravni šole) niso bile dodane. Predpostavljen model je bil ocenjen $\mathrm{z}$ metodo največjega verjetja (angl. maximum likelihood, ML). Delež pojasnjene variance na obeh ravneh je bil izračunan po formuli Snijdersa in Boskerja (1999; opisano v Roberts, Monaco, Stovall in Foster, 2011), saj je privzeti način izračuna vodil do negativnih vrednosti ocen variance na drugem nivoju.

\section{Rezultati}

\section{Uvodne analize}

Najprej smo opravile konfirmatorno faktorsko analizo na vseh uporabljenih merah. Pri delovni zavzetosti se je kot najprimernejši pokazal trifaktorski model, $\chi^{2}(24)=190,659$; $\mathrm{TLI}=0,89 ; \mathrm{CFI}=0,93 ;$ RMSEA $=0,14 ;$ SRMR $=0,07$. Prileganje trifaktorskega modela je bilo sicer bolj primerno kot prileganje enofaktorskega modela, $\chi^{2}(27)=326,65$; TLI $=0,82 ;$ CFI $=0,87$; RMSEA $=0,18 ;$ SRMR $=0,06$, prileganje bolj kompleksnega modela $\mathrm{z}$ manj stopnjami svobode je bilo tudi statistično značilno boljše, $\Delta \chi^{2}(3)=135,99$; $p<0,001$. Vseeno je bilo prileganje trifaktorskega modela nezadovoljivo, analize pa so pokazale, da upoštevanje korelacij med pomensko sorodnimi postavkami utegne prispevati $\mathrm{k}$ izboljšanju prileganja. $\mathrm{V}$ dodatni analizi smo zato preverile prileganje modela, v katerem smo korelirale dva para postavk vprašalnika zavzetosti. Korelacije med dvema rezidualoma oziroma napakama, ki jih ni mogoče pojasniti z latentnim faktorjem ( $\mathrm{v}$ tem primeru $\mathrm{z}$ zavzetostjo), najverjetneje izboljšajo prilaganje modela, ker z njimi vzamemo v obzir, da je lahko za korelacijo med dvema trditvama odgovoren še en dejavnik (ne zgolj predpostavljen latentni faktor). Največkrat je to neka slovnična ali pretirana vsebinska podobnost trditev ali pa celo seštevnost (torej da maksimalno strinjanje $\mathrm{z}$ eno trditvijo nekako nujno pomeni, da se bomo popolnoma strinjali $\mathrm{z}$ drugo trditvijo). V kontekstu konfirmatorne faktorske analize to pomeni, da s tovrstno korelacijo med napakami 
Tabela 1. Opisne statistike ter korelacije med spremenljivkami na ravni posameznikov

\begin{tabular}{|c|c|c|c|c|c|c|c|c|c|}
\hline & $M$ & $S D$ & 1 & 2 & 3 & 4 & 5 & 6 & 7 \\
\hline 1. Splošne delovne zahteve & 4,43 & 0,59 & $(, 86)$ & & & & & & \\
\hline 2. Avtonomija & 4,07 & 0,72 &, 08 & $(, 74)$ & & & & & \\
\hline 3. Opora sodelavcev & 4,11 & 0,67 &, $12^{*}$ &, $32^{* * *}$ & $(, 83)$ & & & & \\
\hline 4. Opora nadrejenih & 4,01 & 0,77 & 03 &, $34^{* * *}$ &, $53^{* * *}$ & $(, 86)$ & & & \\
\hline 5. Površinsko delovanje & 2,43 & 0,73 & ,09 &,$- 12^{*}$ &,$- 19^{* *}$ &,$- 14^{* *}$ & $(, 90)$ & & \\
\hline 6. Globinsko delovanje & 3,28 & 0,82 & 09 & ,06 &, 06 &, 07 &,- 10 & $(, 82)$ & \\
\hline 7. Delovna zavzetost & 4,31 & 0,93 &,- 04 & $28^{* * *}$ &, $21^{* * *}$ & $23^{* * *}$ &,$- 22^{* * *}$ &, $35^{* * *}$ & $(, 85)$ \\
\hline
\end{tabular}

Opombe. Spremenljivka zavzetost temelji na sedemstopenjski ocenjevalni lestvici, ostale spremenljivke pa na petstopenjski ocenjevalni lestvici. Višje vrednosti predstavljajo višjo stopnjo izraženosti spremenljivke. Na diagonali v oklepajih so prikazani Cronbachovi alfa koeficienti notranje skladnosti posameznih dimenzij. ${ }^{*} p<, 05 ;{ }^{* *} p<, 01 ;{ }^{* * *} p<, 001$.

izboljšamo prileganje modela. Korelirale smo napake med sledečima paroma trditev: Pri svojem delu prekipevam od energije. in Pri delu se počutim svežega /-o in dejavnega/-no. ter Moje delo me kar potegne vase« in »Kadar delam, sem prevzet/- a nad delom.« Popravljen trifaktorski model je kazal boljše prileganje, $\chi^{2}(22)=72,00 ;$ TLI $=0,96 ;$ CFI $=0,98$; RMSEA $=0,08 ;$ SRMR $=0,03$, ki je bilo tudi statistično značilno boljše kot prileganje nepopravljenega modela, $\Delta \chi^{2}(2)=118,66 ; p<0,001$. Nasičenosti postavk s faktorji so presegale vrednosti 0,60 (najnižja nasičenost je bila 0,69 ). Postavke so tudi bile ustrezno nasičene s predvidenimi tremi faktorji (energija, zatopljenost, predanost). Kljub trifaktorski strukturi se krajši instrument delovne zavzetosti večinoma uporablja na ravni enega faktorja, kar potrjujejo tudi zelo visoke korelacije med faktorji na našem vzorcu $(>0,90)$.

Konfirmatorna faktorska analiza vprašalnika splošnih delovnih zahtev in virov je pokazala dobro prileganje štirifaktorskega modela, $\chi^{2}(98)=207,43 ;$ TLI $=0,95$; $\mathrm{CFI}=0,96$; RMSEA $=0,06$; $\mathrm{SRMR}=0,06$, pri katerem je bila vsaka izmed postavk nasičena $\mathrm{z}$ ustreznim latentnim faktorjem. Vse nasičenosti so bili višje od 0,40 . Na podlagi tega lahko zaključimo, da lahko zadovoljivo razločujemo med splošnimi delovnimi zahtevami, avtonomijo, oporo sodelavcev in nadrejenih. Nazadnje smo izvedle tudi konfirmatorno faktorsko analizo vprašalnika čustvenega dela. V analize nismo vključile trditve o trajanju interakcij z drugimi osebami pri delu, ki se navadno obravnava ločeno. Predpostavljen petfaktorski model se je zadovoljivo prilegal podatkom, $\chi^{2}(67)=170,68 ;$ TLI $=0,94 ;$ CFI $=0,96$; RMSEA $=0,07$; $\mathrm{SRMR}=0,05$. Vse postavke so bile nasičene $\mathrm{z}$ ustreznimi faktorji (vse nasičenosti nad 0,60), dodatno pa se je pokazalo, da lahko površinsko in globoko igranje obravnavamo kot dva ločena vidika čustvenega dela.

\section{Opisne statistike in korelacije med spremenljivkami}

Osnovne opisne statistike in Pearsonovi koeficienti korelacije med uporabljenimi spremenljivkami so prikazani v tabeli 1. Rezultati korelacijske analize kažejo, da splošne delovne zahteve niso statistično značilno povezane $\mathrm{z}$ delovno zavzetostjo, medtem ko so delovni viri (avtonomija, opora sodelavcev in opora nadrejenih) pozitivno povezani z delovno zavzetostjo. Izmed čustvenih zahtev delovnega mesta je površinsko delovanje šibko, a statistično značilno negativno povezano $\mathrm{z}$ delovno zavzetostjo, globinsko pa zmerno pozitivno. Vse korelacije $\mathrm{z}$ delovno zavzetostjo, $\mathrm{z}$ izjemo splošnih delovnih zahtev, so statistično značilne na ravni tveganja $p<0,001$. Izpostaviti velja še, da je površinsko delovanje negativno povezano $\mathrm{z}$ avtonomijo ter socialno oporo (sodelavcev in nadrejenih) na delovnem mestu, medtem ko je vzorec korelacij globinskega delovanja $\mathrm{z}$ avtonomijo in socialno oporo šibkejši in statistično neznačilen. Prav tako obe vključeni dimenziji čustvenega dela ne korelirata statistično značilno s splošnimi delovnimi zahtevami. Glede na odgovorni format pri vprašalniku delovnih zahteve in virov (tj. petstopenjska ocenjevalna lestvica) je mogoče sklepati, da učitelji v osnovni šoli zaznavajo visoke zahteve, a obenem tudi veliko količino virov pri delu.

\section{Napovedniki delovne zavzetosti}

Večnivojsko regresijsko analizo smo opravile $\mathrm{v}$ več korakih (tabela 2). Najprej smo preverile prazen oz. ničelni model. Rezultati so pokazali, da lahko 9,4\% variance v delovni zavzetosti pripišemo razlikam med šolami, kar kaže na pomembnost nadzorovanja učinka šole $v$ nadaljnjih statističnih analizah. $\mathrm{Z}$ modelom 1 , v katerem smo dodatno definirale napovednike na individualni ravni, vezane na splošne značilnosti delovnih mest (tj. splošne delovne zahteve, avtonomija, opora sodelavcev in opora nadrejenih), smo pojasnile $8,8 \%$ rezidualne variance in približno $0,8 \%$ variance $\mathrm{v}$ delovni zavzetosti na ravni šol. Kot statistično pomembna napovednika delovne zavzetosti sta se pokazala avtonomija in opora s strani nadrejenih. $Z$ večjo avtonomijo in Z višjo stopnjo opore nadrejenih je bila povezana višja stopnja delovne zavzetosti. V model 2 smo dodatno vključile oba vidika čustvenega dela (tj. površinsko in globoko delovanje). Rezultati so pokazali, da sta tako površinsko kot globinsko delovanje bila statistično značilna napovednika delovne zavzetosti, in sicer je površinsko delovanje povezano z nižjo delovno zavzetostjo, medtem ko je globinsko delovanje povezano z višjo delovno zavzetostjo. S končnim modelom smo dodatno pojasnile $12 \%$ variance na ravni posameznika ter zanemarljivo vrednost variance na ravni šole. 
Tabela 2. Rezultati večnivojske regresijske analize za napovedovanje delovne zavzetosti na ravni posameznikov

\begin{tabular}{|c|c|c|c|c|c|c|c|c|c|c|c|c|}
\hline \multirow[b]{2}{*}{ Spremenljivke } & \multicolumn{4}{|c|}{ Ničelni model } & \multicolumn{4}{|c|}{ Model 1} & \multicolumn{4}{|c|}{ Model 2} \\
\hline & $\gamma$ & $S E$ & $t$ & $p$ & $\gamma$ & $S E$ & $t$ & $p$ & $\gamma$ & $S E$ & $t$ & $p$ \\
\hline Presečišče & 4,34 & 0,08 & 54,18 & $<, 001$ & 4,34 & 0,08 & 54,34 & $<, 001$ & 4,34 & 0,08 & 54,53 & $<, 001$ \\
\hline \multicolumn{13}{|l|}{ Raven posameznika } \\
\hline Splošne delovne zahteve & & & & & $-0,09$ & 0,08 & $-1,17$ & ,244 & $-0,10$ & 0,08 & $-1,30$ & , 194 \\
\hline Avtonomija & & & & & 0,29 & 0,07 & 4,14 & $<, 001$ & 0,26 & 0,07 & 4,02 & $<, 001$ \\
\hline Opora sodelavcev & & & & & 0,05 & 0,09 & 0,54 &, 592 & 0,05 & 0,08 & 0,58 & ,565 \\
\hline Opora nadrejenih & & & & & 0,16 & 0,08 & 2,08 & 037 & 0,13 & 0,07 & 1,80 &, 072 \\
\hline Površinsko delovanje & & & & & & & & & $-0,1$ & 0,06 & $-2,55$ &, 011 \\
\hline Globinsko delovanje & & & & & & & & & 0,36 & 0,05 & 6,71 & $<, 001$ \\
\hline Varianca na 1. ravni $(S E)$ & \multicolumn{4}{|c|}{$0,784(0,062)$} & \multicolumn{4}{|c|}{$0,704(0,055)$} & \multicolumn{4}{|c|}{$0,602(0,047)$} \\
\hline Varianca na 2. ravni $(S E)$ & \multicolumn{4}{|c|}{$0,082(0,041)$} & \multicolumn{4}{|c|}{$0,086(0,041)$} & \multicolumn{4}{|c|}{$0,093(0,041)$} \\
\hline
\end{tabular}

\section{Razprava}

Osrednji namen raziskave je bil preveriti, v kolikšni meri zaznane značilnosti delovnega mesta, opredeljene kot delovne zahteve (delovne obremenitve) in delovni viri (opora sodelavcev in nadrejenih, avtonomija), ter samoporočana zmožnost uporabe globinskih in površinskih strategij čustvenega dela napovedujejo delovno zavzetost učiteljev osnovne šole. Rezultati so pokazali, da predstavljata avtonomija in uporaba globinskih strategij čustvenega dela pozitivna napovednika delovne zavzetosti učiteljev, uporaba površinskih strategij čustvenega dela pa negativno napoveduje delovno zavzetost. V raziskavo vključeni napovedniki so pojasnili približno $19 \%$ variance v delovni zavzetosti.

Učitelji, ki v svojem delovnem okolju zaznavajo več avtonomije, so pri delu bolj zavzeti; ugotovitev potrjuje avtonomijo kot pomemben delovni vir na delovnem mestu učitelja in je skladna $\mathrm{z}$ ugotovitvami drugih raziskav (npr. Hakanen idr., 2006), kakor tudi s teoretskimi konceptualizacijami delovne zavzetosti (npr. teorija samodoločanja, Ryan in Deci, 2000). Splošne delovne obremenitve $\mathrm{V}$ nasprotju $\mathrm{z}$ našimi predvidevanji ne napovedujejo delovne zavzetosti, kar pa je vendarle skladno $\mathrm{z}$ ugotovitvami drugih raziskav (npr. Goering, Shimazu, Zhou, Wada in Sakai, 2017; Hakanen idr. 2006), da delovni viri v večji meri napovedujejo pozitivne izide, delovne zahteve pa negativne izide. Podobno so tudi na vzorcu slovenskih učiteljev Košir idr. (2014) ugotovile, da predstavljajo delovne zahteve najmočnejši napovednik doživljanja stresa, emocionalne izčrpanosti in depersonalizacije. Nekoliko presenetljivo je, da se opora sodelavcev in nadrejenih nista pokazala kot statistično značilna napovednika delovne zavzetosti učiteljev. Analiza korelacij med spremenljivkami je sicer pokazala, da je odnos med obema vrstama opore in delovno zavzetostjo statistično značilno pozitiven in zmerno visok. V zvezi $\mathrm{s}$ tem kot eno izmed omejitev raziskave izpostavljamo, da smo izmerile le zaznano stopnjo opore v delovnem okolju, ne pa tudi njene zaznane kakovosti v smislu instrumentalne in čustvene opore pri izboljševanju lastne prakse. Slednje utegne delno pojasniti odsotnost statistično značilnih učinkov obeh vrst opore pri napovedovanju delovne zavzetosti. Košir, Tement, Licardo in Habe (2015) so namreč ugotovile, da je opora sodelavcev varovalni dejavnik pred doživljanjem stresa le pri učiteljih z nizko stopnjo refleksije, ne pa tudi pri tistih, ki so poročali o visoki stopnji refleksije, na osnovi česar so predpostavile, da je opora, ki so je učitelji deležni s strani kolektiva, pogosto usmerjena $\mathrm{v}$ manj produktivne načine zmanjševanja čustvene stiske kot $\mathrm{v}$ oporo pri izboljšanju učinkovitosti dela in konstruktivnemu reševanju problemov. Domnevamo lahko, da predstavlja kakovost opore sodelavcev in nadrejenih dejavnik, ki bi utegnil moderirati odnos med stopnjo zaznane opore in delovno zavzetostjo. To domnevo bi bilo vsekakor potrebno preveriti v prihodnjih raziskavah. V splošnem so odnosi med vključenimi delovnimi zahtevami in viri ter delovno zavzetostjo, kot je razvidno iz analize korelacij med spremenljivkami, skladni s predpostavkami modela delovnih zahtev in virov (Bakker in Demerouti, 2007), saj se splošne delovne zahteve ne povezujejo $z$ delovno zavzetostjo, vsi trije delovni viri pa se $\mathrm{z}$ delovno zavzetostjo povezujejo pozitivno.

Ključni namen raziskave je bil preveriti, ali čustveno delo učiteljev pojasnjuje dodatni delež variance v delovni zavzetosti, ki ga ni mogoče pojasniti z zaznanimi značilnostmi delovnega okolja, ter kakšen je odnos med površinskim ter globinskim čustvenim delom in delovno zavzetostjo. Rezultati so pokazali, da s čustvenim delom pojasnimo relevanten delež rezidualne variance. Ta delež je tudi večji kot delež ostalih delovnih zahtev in virov skupaj. Površinsko delovanje predstavlja negativen napovednik delovne zavzetosti, kar pomeni, da učitelji, ki se v situacijah, ki od njih zahtevajo vedenje, ki ni skladno z njihovim doživljanjem, zaželen odziv pogosteje odigrajo, poročajo o nižji delovni zavzetosti. Nasprotno se je globinsko delovanje pokazalo kot pozitiven napovednik delovne zavzetosti; učitelji, ki zmorejo v situacijah, kjer je od njih zahtevano izražanje čustev, ki jih spontano ne občutijo, svoja čustva regulirati tako, da je njihov odziv pristen, poročajo o višji stopnji delovne zavzetosti. Rezultati naše raziskave torej podpirajo domnevo, da predstavlja zmožnost globinskega čustvenega delovanja delovni vir, medtem ko je površinsko čustveno delovanje delovna zahteva. Ta ugotovitev je skladna $\mathrm{z}$ ugotovitvami nekaterih drugih raziskav, ki kažejo, da uporaba površinskih strategij čustvenega dela predstavlja dejavnik tveganja, uporaba globinskih strategij čustvenega dela pa varovalni dejavnik za pozitivne izide 
(Philipp in Schüpbach, 2010; Yang in Li, 2009). Globinsko čustveno delo kot delovni vir se je v naši raziskavi pokazalo kot močnejši napovednik delovne zavzetosti kot površinsko čustveno delo kot delovna zahteva, kar je skladno s tezo, da delovni viri močneje napovedujejo pozitivne delovne izide, delovne zahteve pa se v večji meri povezujejo z negativnimi delovnimi izidi. O slednjem poročata tudi Brotheridge in Grandey (2002), ki sta ugotovili, da se površinsko čustveno delovanje močneje povezuje $\mathrm{z}$ dimenzijami izgorelosti kot globinsko čustveno delovanje.

\section{Zaključki in smernice}

Kot ključen doprinos raziskave izpostavljamo dve ugotovitvi. Ugotovitev, da delovni viri načeloma močneje napovedujejo delovno zavzetost kot delovne zahteve (splošne delovne zahteve se z delovno zavzetostjo sploh ne povezujejo, površinsko čustveno delovanje je šibkejši napovednik delovne zavzetosti kot globinsko čustveno delovanje) se zdi pomembna $\mathrm{z}$ vidika teoretske konceptualizacije koncepta delovne zavzetosti, predvsem njenega odnosa do izgorelosti. Iz pojmovanja delovne zavzetosti in poklicne izgorelosti kot dveh polov istega kontinuuma bi izhajalo, da delovni viri pozitivno napovedujejo delovno zavzetost in negativno poklicno izgorelost, delovne zahteve pa negativno napovedujejo delovno zavzetost in pozitivno poklicno izgorelost. Naša raziskava je ena izmed mnogih (npr. Schaufeli, Taris in Van Rhenen, 2008), ki te teze ne potrjujejo, kar govori bolj v prid tezi o delovni zavzetosti in poklicni izgorelosti kot dveh ločenih, delno prekrivajočih se konstruktih in ne različnih polih enega konstrukta. Pri tem je seveda treba poudariti, da so za veljavno preverjanje odnosa med konstruktoma delovne zavzetosti in poklicne izgorelosti potrebne raziskave s kompleksnejšimi raziskovalnimi načrti in da je ugotovitev naše raziskave le posredni pokazatelj odnosa med konstruktoma delovne zavzetosti ter poklicne izgorelosti. Vendarle pa predstavlja pričujoča raziskava $\mathrm{v}$ slovenskem okolju pomemben doprinos, saj nakazuje, da za spodbujanje delovne zavzetosti ne zadostuje odsotnost (pre)visokih stresorjev $\mathrm{v}$ delovnem okolju (torej delovnih zahtev), pač pa je potrebno v delovnem okolju krepiti tiste vidike, ki predstavljajo delovne vire. $\mathrm{Na}$ našem vzorcu se je kot pomemben delovni vir, ki se povezuje $\mathrm{z}$ delovno zavzetostjo, pokazala avtonomija, tj. delovni vir, ki ga kot enega izmed ključnih za kakovostno poučevanje poudarjajo tudi raziskave, ki preučujejo dejavnike kakovostnega učenca. Tako npr. Niemiec in Ryan (2009) izhajajoč iz teorije samodoločanja opozarjata, da je za spodbujanje bolj ponotranjenih oblik motivacije učencev za učenje ključno, da tudi učitelji svoje delovno okolje zaznavajo kot tako, ki podpira njihovo avtonomijo pri poučevanju - le v tem primeru bodo lahko učno okolje za učence strukturirali tako, da jim bodo omogočali primerno stopnjo avtonomije pri usmerjanju lastnega učenja.

Druga pomembna ugotovitev pričujoče raziskave je, da globinsko čustveno delo izmed vseh vključenih dejavnikov najmočneje napoveduje zavzetost. Učitelji, ki so poročali, da zmorejo izražanje čustev uravnavati tako, da čustva, ki naj bi jih izrazili, tudi dejansko občutijo, torej delujejo pristno, poročajo o višji stopnji delovne zavzetosti. Površinsko čustveno delo, torej igranje zaželenih čustev pri delu z učenci, se $\mathrm{z}$ delovno zavzetostjo povezuje negativno. Ugotovitev ne potrjuje mita, ki sicer ni evidentiran, ga pa vendarle pogosto srečamo kot implicitno prepričanje med učitelji, namreč da predanost in poskusi razumevanja perspektive učencev za duševno zdravje učiteljev niso ugodni (npr. v obliki Če ti bo preveč mar za učence, boš še izgorel/-a.). V prihodnjih raziskavah bi bilo smiselno preveriti tudi odnos med strategijami čustvenega dela in izgorelostjo pri učiteljih. $\mathrm{V}$ zvezi s tem je zanimiva tudi ugotovitev, da se socialna opora (sodelavcev, nadrejenega) sicer pozitivno povezuje $\mathrm{z}$ delovno zavzetostjo, vendar pa se ni pokazala kot statistično pomemben napovednik delovne zavzetosti. Ugotovitve naše raziskave nakazujejo, da je potrebno na šolah spodbujati takšno socialno oporo, ki prispeva k zmožnosti učiteljev za globinsko čustveno delovanje. Gre torej za uvajanje različnih pristopov (npr. supervizija, intervizija, kolegialna pomoč), ki presegajo nudenje opore v smislu zgolj omogočanja izražanja negativnih čustev, ampak podprejo zmožnost učiteljev, da se urijo v vlogi reflektivnega praktika, torej v zmožnostih poglobljenega reflektiranja lastnega dela na način sprejemanja odgovornosti za spreminjanje svojega pedagoškega dela $\mathrm{v}$ vidikih, na katere učitelji lahko vplivajo. To se zdi še posebej pomembno, ker metaanalitične raziskave (za pregled glej Hattie, 2009), ki so preučevale ključne dejavnike uspešnega učenja, kažejo, da učno okolje, v katerem si učitelji stalno in po možnosti ob podpori kolegov prizadevajo razumeti vpliv, ki ga imajo na kakovostno učenje svojih učencev, ne prispeva le $\mathrm{k}$ nižji stopnji neproduktivnega stresa in višji stopnji delovne zavzetosti učiteljev, pač pa je tudi ključni dejavnik spodbujanja kakovostnega učenja učencev.

Kot eno pomembnih prednosti raziskave velja izpostaviti relativno velik vzorec sodelujočih učiteljev in šol, s čimer smo dobile informacije tudi o variabilnosti, ki jo predstavljajo razlike med šolami. Prav tako nam je velik vzorec omogočil preverjanje psihometričnih značilnosti uporabljenih instrumentov. Obenem je pri interpretaciji potrebno upoštevati tudi nekaj omejitev pričujoče raziskave. Rezultati temeljijo zgolj na samoporočanih podatkih, kar lahko vodi v pristranost rezultatov zaradi uporabe enake metode. $V$ prihodnjih študijah je potrebno to omejitev nasloviti $z$ uporabo več različnih virov podatkov. Prav tako je ena izmed pomembnih omejitev raziskave prečni raziskovalni načrt, ki onemogoča sklepanje na vzročno posledične odnose med spremenljivkami. Možno bi bilo namreč sklepati tudi na obraten proces, saj je mogoče tudi, da delovna zavzetost vpliva na odnos in vedenje pri delu, zato je potrebno načrtovati longitudinalne raziskave skozi daljše časovno obdobje, da dobimo boljši vpogled v odnose med spremenljivkami. Rezultati raziskave so prav tako pokazali, da obstajajo pomembne razlike med šolami $\mathrm{v}$ delovni zavzetosti. $\mathrm{V}$ prihodnje bi bilo zanimivo preveriti, kateri dejavniki na ravni šole lahko pojasnjujejo te razlike (npr. šolska klima, organizacija dela) ter ali katera izmed spremenljivk na ravni šole moderira odnos med čustvenim delom in delovno zavzetostjo. 


\section{Literatura}

Bakker, A. B. in Ball, P. M. (2010). Weekly work engagement and performance: A study among starting teachers. Journal of Occupational and Organizational Psychology, 83, 189-206.

Bakker, A. B. in Demerouti, E. (2007). The job demandsresources model: State of the art. Journal of Managerial Psychology, 22, 309-328.

Bakker, A. B., Demerouti, E., de Boer, E. in Schaufeli, W. B. (2003). Job demands and job resources as predictors of absence duration and frequency. Journal of Vocational Behavior, 62, 341-356.

Bakker, A. B., Hakanen, J. J., Demerouti, E. in Xanthopoulou, D. (2007). Job resources boost work engagement, particularly when job demands are high. Journal of Educational Psychology, 99, 274-284.

Bakker, A. B., Schaufeli, W. B., Leiter, M. P. in Taris, T. W. (2008). Work engagement: An emerging concept in occupational health psychology. Work and Stress, 22, 187-200.

Bear, G. G., Gaskins, C., Blank, J. in Chen, F. F. (2011). Delaware School Climate Survey-Student: Its factor structure, concurrent validity, and reliability. Journal of School Psychology, 49, 157-174.

Boyar, S. L., Carr, J. C., Mosley, D. C. in Carson, C. M. (2007). The development and validation of scores on perceived work and family demand scales. Educational and Psychological Measurement, 67, 100-115.

Brotheridge, C. M. in Grandey, A. A. (2002). Emotional labor and burnout: Comparing two perspectives of "people work”. Journal of Vocational Behavior, 60, 17-39.

Brotheridge, C. M. in Lee, R. T. (2003). Development and validation of the emotional labour scale. Journal of Occupational and Organizational Psychology, 76, 365-379.

Brown, T. A. (2006). Confirmatory factor analysis for applied research. New York, NY, ZDA: Guilford Press.

Cornelius-White, J. (2007). Learner-centered teacher-student relationships are effective: A meta-analysis. Review of Educational Research, 77, 113-143.

Demerouti, E., Bakker, A. B., Nachreiner, F. in Schaufeli, W. B. (2001). The job demands-resources model of burnout. Journal of Applied Psychology, 86, 499-512.

Goering, D. D., Shimazu, A., Zhou, F., Wada, T. in Sakai, E. (2017). Not if, but how they differ: A meta-analytic test of the nomological networks of burnout and engagement. Burnout Research, 5, 21-34.

González-Romá, V., Schaufeli, W. B., Bakker, A. B. in Lloret, S. (2006). Burnout and work engagement: Independent factors or opposite poles? Journal of Vocational Behavior, 62, 165-174.

Habe, K. in Tement, S. (2016). Flow among higher education teachers: A job demands-resources perspective. Psihološka obzorja, 25, 29-37.

Hakanen, J. J., Bakker, A. B. in Schaufeli, W. B. (2006). Burnout and work engagement among teachers. Journal of School Psychology, 43, 495-513.
Hakanen, J. J., Schaufeli, W. B. in Ahola, K. (2008). The Job Demands-Resources model: A three-year cross-lagged study of burnout, depression, commitment, and work engagement. Work and Stress, 22, 224-241.

Hallberg, U. in Schaufeli, W. B. (2006). 'Same same' but different: Can work engagement be discriminated from job involvement and organizational commitment? European Journal of Psychology, 11, 119-127.

Hattie, J. (2009). Visible learning. A synthesis of over 800 meta-analyses relating to achievement. New York, NY, ZDA: Routledge.

Hattie, J. in Anderman, E. M. (ur.). (2013). International guide to student achievement. New York, NY, ZDA: Routledge.

Hochschild, A. R. (1983). The managed heart: The commercialization of human feeling. Berkeley, CA, ZDA: UCP.

Hülsheger, U. R. in Schewe, A. F. (2011). On the costs and benefits of emotional labor: Meta-analysis of three decades of research. Journal of Occupational Health Psychology, 16, 361-389.

Judge, T., Woolf, E. in Hurst, C. (2009). Is emotional labor more difficult for some than for others? A multilevel, experience-sampling study. Personnel Psychology, 62, $57-88$.

Karasek, R., Brisson, C., Kawakami, N., Houtman, I., Bongers, P. in Amick, B. (1998). The Job Content Questionnaire (JCQ): An instrument for internationally comparative assessments of psychosocial job characteristics. Journal of Occupational Health Psychology, 3, 322-355.

Košir, K. (2017). Pedagoška psihologija za učitelje [Educational psychology for teachers]. Maribor, Slovenija: Univerzitetna založba Univerze v Mariboru in Pedagoška fakulteta Univerze v Mariboru.

Košir, K., Licardo, M, Tement, S. in Habe, K. (2014). Doživljanje stresa in izgorelosti, povezanih $\mathrm{z}$ delom $\mathrm{Z}$ učenci s posebnimi potrebami pri učiteljih $\mathrm{v}$ osnovni šoli [Experiencing stress and burnout in primary school teachers working with special needs students]. Psihološka obzorja, 23, 110-124.

Košir, K., Pivec, T., Klasinc, L., Špes, T. in Horvat, M. (2018). Psihosocialne značilnosti učencev kot napovedniki različnih oblik medvrstniške viktimizacije in nasilnega vedenja [Psychosocial characteristics of students as determinants of various forms of peer victimization and violent behaviour]. Psihološka obzorja, 27, 171-186.

Košir, K., Tement, S., Licardo, M. in Habe. K. (2015). Two sides of the same coin? The role of rumination and reflection in elementary school teachers' classroom stress and burnout. Teaching and Teacher Education, 47, 131-141.

McDonald, R. P., in Ho, M. H. R. (2002). Principles and practice in reporting structural equation analyses. Psychological Methods, 7, 64-82.

Muthén, L. in Muthén, B. (1998-2017). Mplus user's guide. Los Angeles, CA, ZDA: Muthén in Muthén.

Niemiec, C. P. in Ryan, R. M. (2009). Autonomy, competence, and relatedness in the classroom: Applying selfdetermination theory to educational practice. Theory and Research in Education, 7, 133-144. 
Philipp, A. in Schüpbach, H. (2010). Longitudinal effects of emotional labor on emotional exhaustion and dedication of teacher. Journal of Occupational Health Psychology, 15, 494-504.

Roberts, J. K., Monaco, J. P., Stovall, H. in Foster, V. (2011). Explained variance in multilevel models. V J. J. Hox in J. K. Roberts (ur.), Handbook of advanced multilevel analysis (str. 219-231). New York, NY, ZDA: Routledge.

Ryan, R. M. in Deci, E. L. (2000). Intrinsic and extrinsic motivations: Classic definitions and new directions. Contemporary Educational Psychology, 25, 54-67.

Schaufeli, W. B. in Bakker, A. B. (2004a). Job demands, job resources and their relationship with burnout and engagement: A multi-sample study. Journal of Organizational Behavior, 25, 293-315.

Schaufeli, W. B. in Bakker, A. B. (2004b). Utrecht Work Engagement Scale Preliminary Manual. Occupational Health Psychology Unit-Utrecht University. Pridobljeno s https://www.wilmarschaufeli.nl/publications/Schaufeli/ Test Manuals/Test manual UWES English.pdf

Schaufeli, W. B., Bakker, A. B. in Salanova, M. (2006). The measurement of work engagement with a short questionnaire: A cross-national study. Educational and Psychological Measurement, 66, 701-716.

Schaufeli, W. B., Taris, T. W. in Bakker, A. B. (2006). Dr Jekyll or Mr Hyde: On the differences between work engagement and workaholism. V R. J. Burke (ur.), Research companion to working time and work addiction (str. 193-217). Northampton, MA, ZDA: Edward Elgar Publishing.

Schaufeli, W. B., Taris, T. W. in Van Rhenen, W. (2008). Workaholism, burnout, and work engagement: Three of a kind or three different kinds of employee well-being? Applied Psychology, 57, 173-203.

Simbula, S., Guglielmi, D. in Schaufeli, W. B. (2011). A threewave study of job resources, self-efficacy, and work engagement among Italian school teachers. European Journal of Work and Organizational Psychology, 20, 285-304.

Slivar, B. (2009). Raziskava o poklicnem stresu pri slovenskih vzgojiteljih in učiteljih: povzetek. Ljubljana, Slovenija: SVIZ Sindikat vzgoje, izobraževanja, znanosti in kulture Slovenije.

Smrke, U. in Tement, S. (2020). Validacija slovenske oblike Vprašalnika čustvenega dela [Validation of Slovenian version of Emotional Labour Questionnaire]. Neobjavljen prispevek, Oddelek za psihologijo, Univerza v Mariboru.

SURS. (2018). Zaposleni v formalnem izobraževanju, Slovenija, šolsko leto 2016/2017 in 2017/2018 [Employees in formal education, Slovenia, school year 2016/2017 and 2017/2018]. Pridobljeno s https://www.stat. si/statweb/News/Index/7065

Taris, T. W, Ybema, J. W. in van Beek, I. (2017). Burnout and engagement: Identical twins or just close relatives? Burnout Research, 5, 3-11.

Tement, S. (2014). The role of personal and key resources in the family-to-work enrichment process. Scandinavian Journal of Psychology, 55, 489-496.
Tement, S. in Korunka, C. (2013). Does trait affectivity predict work-to-family conflict and enrichment beyond job characteristics? Journal of Psychology: Interdisciplinary and Applied, 147, 197-216.

Tement, S., Korunka, C. in Pfifer, A. (2010). Toward the assessment of the work-family interface: Validation of the Slovenian versions of work-family conflict and workfamily enrichment scales. Psihološka obzorja, 19, 53-74.

Tösten, R. in Sahin, C. (2017). Examining the teachers' emotional labor behavior. Journal of Education and Training Studies, 5, 18-27.

Tsang, K. K. (2011). Emotional labor of teaching. Educational Research, 2, 1312-1316.

Watt, H. M. G. in Richardson, P. W. (2013). Teacher motivation and students achievement outcomes. V J. Hattie in E. M. Anderman (ur.), International guide to student achievement (str. 271-273). New York, NY, ZDA: Routledge.

Yang, L. in Li, M. J. (2009). The relationship among emotion work strategies, characters and job satisfaction in primary and middle school teachers. Psychological Development and Education, 3, 89-100. 